\title{
Gdynia - miasto z morza, marzeń (i z paradoksów)
}

\section{Mieczysław Kochanowski, Danuta Kochanowska}

\author{
STRESZCZENIE
}

Port i miasto Gdynia powstały, bo taka była polityczna i ekonomiczna konieczność odrodzonego po I Wojnie Światowej państwa polskiego. O sukcesie budowy zdecydowała determinacja państwa i entuzjazm obywateli, a budowa Gdyni to początek morskiej tradycji Polski i jej nowoczesnego społeczeństwa. To także wybitny przykład architektury modernistycznej.

Słowa kluczowe: miasto i port - społeczeństwo - modernizm

\section{Dzieje budowy miasta}

Przed wojną ukazał się pięknie wydany album opisujący powstanie Gdyni pod tytułem Miasto z morza i z marzeń. Tytuł ten wkrótce się upowszechnił szeroko, stając się swego rodzaju dewizą Gdyni. Widać dobrze oddawał istotę tego miasta. Chcąc jednak pełniej zrozumieć jego genezę i burzliwą historię, trzeba zauważyć, że o powstaniu Gdyni zadecydował w niemałym stopniu swoisty przypadek czy też szczególny kaprys historii.

Porty północnoeuropejskie powstawały, prawie zawsze, jako porty ujściowe bądź nawet były sytuowane w dolnym biegu rzek, niekiedy w znacznej odległości od otwartego morza. Takie są porty w Szczecinie, Hamburgu, Rotterdamie, Londynie ..., taki jest port gdański.

Gdynia do nich nie należy. Jej lokalizacja została wymuszona uwarunkowaniami politycznymi. Głębokość portowego akwenu, sięgająca przy nabrzeżach Francuskim i Holenderskim 15 metrów, przed wojną wydawała się wystarczająca. Po wojnie, a szczególnie po okresowym zamknięciu kanału Sueskiego, zaczęła się epoka ogromnych statków, o większym zanurzeniu, głębokość basenów portu gdyńskiego okazała się dla nich niewystarczająca. Pod tym względem wybudowany w Gdańsku w latach 70. XX w. Port Północny miał o wiele lepsze warunki rozwojowe: korzystne warunki batymetryczne i rozległe zaplecza lądowe. Można więc mniemać, że twórcy portu - z Eugeniuszem Kwiatkowskim i Tadeuszem Wendą na czele - nie dysponując szczególnie sprzyjającymi warunkami naturalnymi, musieli zrekompensować ten niedostatek nowoczesnymi rozwiązaniami technicznymi. Dzięki temu, port gdyński, zbudowany „na surowym korzeniu” w zubożałym po wojnach kraju, w warunkach naznaczonych światowym kryzysem i przy braku doświadczeń w gospodarowaniu nad morzem, port „z morza i z marzeń” rychło stał się najnowocześniejszy na Bałtyku!

Również miasto Gdynia, podobnie jak jej port, ponosiło konsekwencje przestrzennych uwarunkowań, a miejscami ograniczeń. Położone między brzegiem morskim, nad którym rozłożył się już port, a linią zalesionych wzgórz morenowych, na stosunkowo wąskim paśmie 


\section{4.}

\section{U s t a w a}

z dnia 23 września 1922 roku

\section{- budowie portu w Gdyni.}

Art. 1. Upoważnia się Rząd do poczynienia wszelkich niezbędnych zarządzeń celem wykonania budowy portu morskiego przy Gdyni na Pomorzu, jako portu użyteczności publicznej.

Art. 2. Budowa portu wykonywana będzie stopniowo według takiego planu, aby przez częściowe jej urzeczywistnienie stworzyć port mniejszych rozmiarów i aby dalszy rozwój portu był możliwy i planowy.

Art. 3. Wywlaszczenie gruntów niezbędnych pod budowe portu przeprowadzone bedzie według ustaw i przepisów, obowiązujących na terytorjum województwa pomorskiego.

Art. 4. Kredyty niezbedne dla budowy portu bądą corocznie wstawiane do budżetu.

Art. 5. Wykonanie niniejszej ustawy porucza się Ministrowi Przemyslu i Handlu w porozumieniu

z Ministrami: Spraw Wojskowych, Skarbu i Robót Publicznych.

Art. 6. Ustawa niniejsza wchodzi w życie $z$ dniem jej ogloszenia.

Marszałek: Trgmpczyríski

Prezydent Ministrów: Juljan Nowak

Kierownik Ministerstwa Przemysłu i Handlu: Henryk Strasburger

Minister Spraw Wojskowych: Sasnkowski

Minister Skarbu: Jastrzębski

Minister Robót Publicznych: Kopuszański 
terenu, nie dysponowało nieograniczonymi zasobami gruntów, pozwalającymi na swobodne kształtowanie przestrzennej struktury i ekstensywnej zabudowy śródmieścia. Gdynia musiała wpisać się w ten układ fizjograficzny, wykorzystując go intensywniej niż można oczekiwać w nowych miastach powstających w "szczerym polu”. Gdynia nie powstawała zresztą w "szczerym polu”; nie było tam wprawdzie urbanizacyjnych zalążków, ale istniała wieś Gdynia, duża i ludna, mająca już kontakty z letnikami. Podnosiło to wprawdzie ceny ziemi i wpływało na intensywność zabudowy, ale nie powstrzymywało napływu ludzi, inwestycji i kapitału.

Stosunkowo wysokie ceny gruntu wymuszały jego intensywne wykorzystanie przez zabudowę, a to przesądzało o swoiście wielkomiejskim charakterze powstającego miasta. Gdynia od początku taka właśnie była. Dziś, kiedy współczesna urbanistyka zaczyna rehabilitować spójność i zwartość struktur miejskich, ponownie jawi się jako miasto nowoczesne! To też jeden z paradoksów, układających się w jej niebanalną historię.

Gdynia to legenda odrodzonej Polski okresu międzywojennego, Polski na morzu, a także polskiej urbanistyki i architektury. Darzymy ją szczególnymi uczuciami i upiększamy jej obraz w naszych wyobrażeniach i wspomnieniach. Zapominamy mimo woli nie tylko o obiektywnych trudnościach, towarzyszących każdemu wielkiemu przedsięwzięciu, ale i o popełnionych błędach, wynikających przeważnie ze specyfiki tego nietypowego przecież pod wieloma względami przedsięwzięcia.

Podstawą prawną budowy portu w Gdyni była ustawa Sejmu RP z dn. 23 września 1922 r. „o budowie portu w Gdyni", zapisana w 6 artykułach i 19 wierszach druku (ryc. 1). Wskazuje ona organa państwa odpowiedzialne za budowę i ogólne zasady realizacji inwestycji. Taka lapidarność ma swe dobre i złe strony. Wyraża zaufanie ustawodawcy do kompetencji i odpowiedzialności wskazanych ministrów i ich służb pozostawiając im znaczny margines swobody w realizacji podejmowanych działań. Z drugiej strony, pozostawiając poza sferą uregulowań ustawowych kwestie szczegółowe, stwarza niebezpieczeństwo braku spójności i wzajemnej nieprzystawalności elementów tego złożonego procesu inwestycyjnego. Przede wszystkim zwraca uwagę fakt, że w ustawie - poświęconej wprawdzie tylko budowie portu - nie pada ani razu słowo „miasto”. Trudno złożyć to wyłącznie na karb lapidarności tego dokumentu.

W 1935 r., nakładem Instytutu Wydawniczego Państwowej Wyższej Szkoły Morskiej w Gdyni, ukazało się zbiorowe opracowanie pt. XV lat polskiej pracy na morzu, zawierające 28 artykułów przygotowanych przez ludzi, którzy tę Gdynię budowali (z Eugeniuszem Kwiatkowskim na czele). Znaczenie tego unikatowego, obszernego materiału polega m.in. na wiarygodności, którą daje znajomość rzeczy i poczucie odpowiedzialności za własną pracę.

Według jego autorów, szczególnie wiele nieporozumień i błędów charakteryzowało pierwszy okres budowy. Budowniczowie miasta, architekt Stanisław Filipkowski i ekonomista Stanisław Malessa piszą:

„Gdy tworzono Gdynię - port i dużo o nim myślano, odsuwano na plan drugi sprawę Gdyni - miasta. Nie podkreślano dość silnie, że wszelkie nici gospodarcze i polityczne wiążące port z państwem i ze światem prowadzą przez to miasto. ... Gdy wybierano 
najdogodniejszą sytuację pobrzeża dla portu nie pomyślano o sytuacyjnych potrzebach miasta i wtłoczono to miasto w wąski trójkąt między portem, morzem a wzgórzami. ... W swoim czasie czynniki urzędowe wyraźnie zaznaczyły, że nie mogą wiązać budowy portu z rozwojem miasta. Pomiędzy portem i miastem powstał chiński mur niezrozumienia. Skutkiem tego miasto rozwijało się w zupełnym oderwaniu od portu" [XV lat polskiej... 1935, s. 282]. Różnice między portem a miastem Gdynią jako przedmiotami tego złożonego procesu inwestycyjnego, podkreślają też inni jego uczestnicy jak np. Komisarz Rządu w Gdyni, Franciszek Sokół. Śledząc burzliwy rozwój miasta uważa on, iż można odnieść wrażenie, że rozwój ten wyznaczały i determinowały nie tyle odpowiednie plany i programy, ile sama dynamika rozwojowa portu, stwarzająca rosnące gwałtownie zapotrzebowanie na siłę roboczą oraz obecne w świadomości społecznej - a może i ogólnonarodowej poczucie szansy awansu nie tylko materialnego i kulturowego, czym dla Polaków było morskie otwarcie na świat, spotkanie nowych ludzi, nowych doświadczeń.

Początkowo widziano przyszłą Gdynię jako ośrodek prowincjonalny do 40 tys. mieszkańców, w połowie obsługujących funkcję turystyczną. Przyjmowane kolejno prognozy zaludnienia i tak zawsze były przekraczane przez realny wzrost. To właśnie zjawisko, obok innych problemów, było w opinii autorów cytowanej wyżej pracy budowniczych Gdyni, jedną z głównych przyczyn utrudniających prawidłowy rozwój miasta. Przy niedostatku terenów budowlanych w śródmieściu i wysokich cenach gruntu oraz wysokich czynszach, ruch ludności napływowej kierował się bowiem na pobliskie, mniejsze miejscowości, które z czasem zaczęły żywiołowo tworzyć wokół Gdyni swego rodzaju układ satelitarny.

„Wszystkie te braki i usterki - piszą dalej Filipkowski i Malessa - których skutki zaczęły się uwypuklać coraz silniej zarówno w życiu miasta jak i portu sprawiły, że Komitet Ekonomiczny Rady Ministrów w roku 1933 powołał do życia specjalną Komisję międzyministerialną powierzając jej ustalenie wytycznych rozwoju portowego miasta Gdyni. Bank Gospodarstwa Krajowego udzielił zarządowi miejskiemu pożyczki dla opracowania zamierzeń programowych ... w tym Ogólnego planu zabudowania portowego miasta Gdyni łącznie ze sferą interesów mieszkaniowych" [XV lat polskiej... 1935, s. 282].

W grudniu tegoż roku zorganizowano przy Komisariacie Rządu w Gdyni Biuro Projektów. Miasto, nie tracąc swej dynamiki, wchodziło w okres porządkowania dotychczasowych i przyszłych wysiłków. Przy opracowaniu programu rozwoju Gdyni przyjęto docelową pojemność miasta na około 250000 mieszkańców.

Gdynia uchodzi dziś za doskonały przykład miasta modernistycznego. Niewątpliwie jest jedynym w Polsce, a także jednym z nielicznych na świecie miast tak silnie naznaczonych charakterystycznymi cechami tego stylu. Nie jest jednak wiernym podporządkowaniem doktrynie modernistycznej, ani ilustracją arbitralnych zaleceń Karty Ateńskiej z 1933 roku. Na szczęście. Dosłownie wdrażane w życie doktryny bywają niebezpieczne - także $\mathrm{w}$ architekturze.

Twórcy modernizmu w architekturze i urbanistyce, inspirowani naukami społecznymi, medycyna, a nawet klimatologia, postrzegali miasto przede wszystkim jako środowisko 
zapewniające ludziom warunki zdrowego życia, a więc jako problem mieszkalnictwa. Stąd ich zainteresowanie koncentrowało się głównie na domu mieszkalnym i osiedlu. Na tym polu powstawały najwybitniejsze osiągnięcia, tak w dziedzinie teorii, jak i praktyki. Śródmieścia były raczej poza zasadniczym nurtem zainteresowań modernistów. Odnoszące się do nich postulaty dotyczyły raczej rozwiązań bardziej szczegółowych, często pochodnych od zalecanych, wywodzących się z problematyki mieszkaniowej.

Mówiąc o Gdyni, jako mieście modernistycznym, mamy na myśli jej charakterystyczną architekturę; rozwiązania urbanistyczne są raczej konwencjonalne. Plan miasta opiera się na klasycznej hippodamejskiej sieci prostokątnej. Tworzyły ją tradycyjne wielofunkcyjne ulice i zawarte między nimi kwartały zabudowy, wypełniane przez ciągła, obrzeżną zabudowę mieszkaniowa $\mathrm{w}$ parterach przeznaczoną na usługi (głównie handel). Dostępne od ulicy, tworzyły ciągi usługowe nadające miastu jego handlowy charakter. Tworzące wzdłuż ulicy ciagłą pierzeję budynki (głównie mieszkalne) nie mogły - siłą rzeczy - być orientowane względem stron świata, czego wymagały kanony modernizmu, a łączenie w nich funkcji mieszkalnych z handlowymi także nie odpowiadało zasadzie segregowania funkcji. Kwartały te były jednak pozbawione oficyn, co różniło je od kwartałów dziewiętnastowiecznych i przez to było tam miejsce na zieleń i urządzenia dla dzieci. Z myślą o bezpieczeństwie dzieci idących do szkoły starano się je lokalizować unikając, w miarę możliwości, kolizji z ruchem kołowym.

Niekonsekwentne wdrażanie doktryn urbanistyki modernistycznej miało też paradoksalnie - swoje dobre strony. Modernizm bowiem - według późniejszych ocen nie wyróżnił się szczęśliwymi rozwiązaniami przestrzeni śródmiejskich. Przyczyny tego tkwiły, m.in. w samej jego doktrynie, negującej radykalnie wielowiekowe doświadczenia miast i nauki stąd płynące. Gdynia uniknęła tego błędu, dlatego też, chociaż modernistyczna, jest bardziej „ludzka”.

Recepty modernistyczne można było natomiast zastosować budując przedmieścia mieszkalne i otaczające Gdynię małe miejscowości, którym można było nadać postać popularnych wtedy satelitów czy przyfabrycznych osiedli, jakie budowano, np. w Niemczech. Tego jednak nie zrobiono, ani przed wojna, ani po niej.

W odróżnieniu od innych wielkich założeń modernistycznych, Gdynia nie powstawała pod dyktando jednego kompleksowego planu, obejmującego zarówno koncepcję całości w skali urbanistycznej, jak i architektoniczne projekty poszczególnych obiektów. Późniejsi historycy zwracali wprawdzie uwagę, że specyficzne dla Gdyni było to, że wielkie kamienice powstawały tu w szczerym polu, podporządkowane tylko liniom regulacyjnym, ale nie oznaczało to jednego, zorganizowanego przedsięwzięcia inwestycyjnego. Poszczególne budynki były dziełami różnych prywatnych inwestorów. Skutkowało to rozmaitością rozwiązań architektonicznych, poddanych wprawdzie jednemu dominującemu wówczas stylowi - modernizmowi, ale na tyle zróżnicowanych, że dawało to efekt bogatej zabudowy miejskiej. Można więc powiedzieć, że powstające budynki były dodawane do istniejącej substancji tak, jak to bywa w tradycyjnych miastach i może właśnie dzięki temu modernistyczna Gdynia wygląda jak „prawdziwe” miasto! 
Mimo, iż przedwojenny czas budowy Gdyni to zaledwie kilkanaście lat, widać wyraźne różnice stylistyczne między budynkami wcześniejszymi a tymi z późniejszych lat 30. W tych ostatnich silniej zarysowały się cechy rekomendowane w Karcie Ateńskiej z 1933 roku. Nie ma wprawdzie ogrodów na płaskich dachach, właściwych dla klimatu śródziemnomorskiego, skąd się wywodza, ani domów na słupach, oddzielających bryłę od fundamentów, ale widać, zwłaszcza na późniejszych obiektach: proste bryły, gładkie ściany i podłużne okna, zajmujące niekiedy całą ścianę łącznie z narożnikami, co świadczy też o ich wewnętrznym układzie konstrukcyjnym. Pojawiły się również oryginalne formy architektoniczne, jak zaokrąlone naroża i okrągłe otwory okienne, inspirowane formami okrętowymi. Miasto demonstrowało z dumą swą morską proweniencję.

Ciekawe, jak rozwijałaby się modernistyczna historia Gdyni, gdyby nie cezura wojenna i powojenna. Dziś architekci gdyńscy próbują nawiązywać do tamtych heroicznych lat, ale ... minęło już pół wieku a Gdynia - mimo wszystko - nie chce być skansenem.

\section{Gdynia w aglomeracji gdańskiej}

Po wojnie Polska uzyskała szeroki dostęp do morza i nie był to już dostęp symboliczny, jak przed wojną. Zyskaliśmy bowiem kilka portów i sytuacja Gdyni nieco się skomplikowała: straciła to co było jej podstawowym atutem - pozycję monopolisty w kraju. Zasadne stawało się pytanie - co dalej? Przecież gdyby po I wojnie światowej Gdańsk przyznano Polsce, Gdynia nigdy by nie powstała. Okazało się jednak, że wygodna pozycja monopolisty nie jest niezbędna, aby miasto i port mogły się rozwijać nie tracąc swej morskiej specyfiki.

Nierównomierne zniszczenia wojenne obu sąsiadujących miast portowych - Gdyni i Gdańska - tworzyły też naturalne przestrzenie do współpracy. Port gdyński był zniszczony, a wejście do niego zatarasowane wielkim wrakiem pancernika Gneisenau; miasto natomiast niemal nie ucierpiało; odwrotnie niż Gdańsk, gdzie w niewielkim stopniu uszkodzony port otoczony był prawie unicestwionym historycznym śródmieściem i mniej zniszczonymi przedmieściami.

Od pierwszych lat powojennych zaczęły się codzienne przejazdy do pracy między obu miastami, czego infrastrukturalną podstawą stała się wybudowana na początku lat 50. Szybka Kolej Miejska. Tak powstała funkcjonalna aglomeracja miejska, uzupełniona Sopotem, nazwana Trójmiastem. Stało się ono szybko, dzięki różnorodnym wartościom, jakie wniosły we wianie jednoczące się miasta, jednym z najważniejszych organizmów miejskich na mapie Polski. Oddzielnie żadna z jego trzech części składowych nie miałaby szans na uzyskanie takiej pozycji. Procesy integracyjnenie wiązały się tu jednak z uniformizacją. Raczej podkreślały to, co było w nich lokalnego i specyficznego, cokolwiek by to znaczyło. Dzięki temu Gdynia zachowała nie tylko swój niepowtarzalny modernistyczny styl i krajobraz, ale i przeniesiony z lat międzywojennych nastrój miasta portowego, o który niełatwo już przecież w nowoczesnych portach.

Nietypowe, tak bliskie sąsiedztwo dwóch dużych portów dało także asumpt do integracji opartej na specjalizacji, wynikającej przede wszystkim z naturalnej predyspozycji każdego z nich oraz ich istotnych elementów. 
Nowy, zbudowany w latach 70., Port Północny Gdańska, wykorzystując odpowiednie po temu warunki batymetryczne, rozwinął przeładunki masowe i obsługę wielkich, o głębokim zanurzeniu kontenerowców. Gdynia, dysponując odbudowaną przedwojenną infrastrukturą portowa, specjalizowała się $\mathrm{w}$ intratnych przeładunkach drobnicy. Dla koordynacji poczynań tych portów powołany został organ pod nazwą Zarząd Portów Gdańsk-Gdynia. Integracja portów, wraz z ich rozbudową i modernizacją znacząco powiększyła ich potencjał przeładunkowy, rozszerzając szczególnie zakres oferowanych przez nie usług.

Pierwsze powojenne dziesięciolecia były zatem okresem najściślejszego związku Gdyni z Gdańskiem. W powszechnej świadomości stanowiły one - wraz z Sopotem jedną aglomeracje - Trójmiasto. Sprzyjały tej integracji warunki ustrojowe - ograniczenia autonomii samorządów lokalnych i centralnie sterowana gospodarka państwowa (w tym zarządzanie portami i infrastrukturą komunalną).

Powołanie de facto jednego organizmu metropolitalnego, powiązanego systemami infrastruktury, tworzyło stosunkowo szerokie możliwości wyboru rozmaitych ofert w obrębie Trójmiasta w zakresie wszystkich funkcji miejskich, mimo ich relatywnie niezbyt wysokiego poziomu $\mathrm{w}$ warunkach powojennego niedostatku. Korzystano $\mathrm{z}$ nich powszechnie, niezależnie od ówczesnego niedorozwoju indywidualnej komunikacji samochodowej.

W latach 90., wraz z transformacją ustrojową sytuacja uległa zmianie. Samorządy lokalne, które „wybiły się na niepodległość”, wejście szerokim frontem własności prywatnej i gospodarki rynkowej, nowe relacje międzynarodowe sprawiły, że nastąpił wyraźny rozdział między Gdańskiem a Gdynią - poszukiwanie lokalnej tożsamości i osłabienie integracji układu metropolitalnego. Ilustracją tego stały się trudności z określeniem jego granic (podzielonego na część gdańską i gdyńską), spory o nazwę metropolii czy o bilet metropolitalny. Następowało stopniowe wypełnianie się tzw. Dolnego Tarasu, tj. względnie płaskiego terenu położonego między brzegiem morza a pasmem wzgórz morenowych. Komunikacja w obrębie tego Tarasu nabierała coraz większego znaczenia, zbliżając się do granic swej wydolności, mimo budowy w latach 70. tzw. Obwodnicy Zachodniej. Pojawiły się - nigdy w pełni niezrealizowane - koncepcje tzw. Drogi Czerwonej, w rodzaju wewnątrzmiejskiej autostrady, prowadzącej wzdłuż osi Dolnego Tarasu.

Transformacja ustrojowa i nowe perspektywy rozwoju gospodarczego dodatkowo zróżnicowały sytuację obu miast. Wprawdzie obydwa przeżyły podobne załamanie przemysłu stoczniowego (m.in. wskutek globalnych procesów jego rozwoju na Dalekim Wschodzie), ale Gdańsk dysponował atutami, związanymi z warunkami naturalnymi, których Gdynia nie miała. Za to dysponowała niezwykle dynamiczną społecznością, o rozwiniętym etosie przedsiębiorczości i gorącym patriotyzmie lokalnym oraz zaangażowaniem w sprawy publiczne.

Źródła uczuć i aktywności mieszkańców miasta można szukać we wciąż żywej pamięci o początkach Gdyni, świadomie wybranej przez pokolenia ich przodków jako „miejsce do życia", ale także w jej wyrazistej formie, związkach z naturą i krajobrazem. 


\section{Rozwój przestrzenny Gdyni}

Dzieje rozwoju przestrzennego Gdyni, jak i powstająca w ich wyniku struktura miejska pełne są paradoksów czy odstępstw od powszechnie obserwowanych zjawisk i procesów. Zadecydowały o tym: historia budowy miasta, (ze szczególnym znaczeniem „nienaturalności” samej decyzji o jej powołaniu w tym miejscu i czasie), warunki naturalne i kulturowy charakter miejsca, w którym powstała, wreszcie swoisty woluntaryzm twórców Gdyni, którzy musieli zmagać się z pewną dozą anarchizmu, towarzyszącą jej rozwojowi.

Niebagatelny wpływ na swoisty charakter przestrzenny Gdyni miały jej wyraziste warunki krajobrazowe - pełne malowniczości i romantyzmu. Podobnie jak sama idea budowy portu i miasta, poruszająca struny romantyzmu ciągnących do niej pionierów.

Nic dziwnego, że budowa nie poddawała się niewolniczo doktrynom urbanistycznym. Brak, np. segregacji funkcji i rygorystycznego stosunku do stron świata, ściślej wiąże Gdynię z uniwersalną postacią miasta. Nie jest więc ona ani klasycznym miastem historycznym, o długim procesie rozwoju, ani typowym miastem modernistycznym.

Wyrazisty układ i wewnętrzna konstrukcja struktury urbanistycznej Gdyni odpowiadają najlepszym wzorcom urbanistyki Hippodamosa z Miletu, a nawet formom lansowanym przez postmodernistyczną reakcję na praktyki Le Corbusiera. Wynikła stąd jej nietypowość, połączona z wyrazistym krajobrazem (brzeg morza i krawędź wzgórz morenowych) nadaje miastu rys malowniczości i oryginalności.

Struktura przestrzenna Gdyni oparta była od początku na prostopadłych wobec siebie kierunkach: Wschód-Zachód i Północ-Południe.

Pierwszy z nich łączył: brzeg morza, Skwer Kościuszki, tereny portowe, dworzec kolejowy; drugi, oparty na historycznym ciągu, stał się główną osią miasta - ul. Świętojańską. Kierunki te orientowały mieszkańców w strukturze miasta, a ich uzupełnieniem były zespoły zieleni, związane z fizjograficznymi, krajobrazowymi kompleksami, takimi jak Kamienna Góra czy Wzgórze Maksymiliana oraz starannie zlokalizowane inne, oryginalne elementy struktury urbanistycznej, w rodzaju skwerów, placów miejskich czy bulwarów (Skwer Kościuszki, Bulwar Nadmorski, założenia związane z funkcjami kulturalnymi).

Omawiane cechy pierwotnej miejskiej struktury Gdyni dały w rezultacie podwójne efekty:

- Stworzyły układ niestandardowy, oryginalny i inspirujący mieszkańców emocjonalnie;

- Przygotowały warunki do reakcji wobec modernizmu, w postaci niezwykłej kariery, jaką od nowego wieku przeżywa pojęcie przestrzeni publicznych.

Stosunek do przestrzeni miejskich, określanych mianem publicznych, był wstępem do głębokich zmian w pojmowaniu roli kluczowych elementów kompozycji miasta, a zarazem sygnałem generalnej zmiany wobec jego struktury, dotąd rozumianej wyłącznie jako sieć sprawnie połączonych węzłów, pobudzająca ruch między nimi. Odtąd przeciwnie - ważna staje się wielofunkcyjność, kompatybilność i złożoność tkanki miasta jako korzystnego środowiska życia ludzi.

Cechy te występowały powszechnie w Gdyni, która wyprzedziła swój czas. Utrzymano w niej Łzw. „ludzką skalę”, nieliczne były ekscesy formalne oraz lekceważenie kontekstu urbanistycznego. 
Ostatnie sekwencje rozwoju przestrzennego miasta - po transformacji ustrojowej wpisały się, choć nie do końca, w etapy ewolucji polskiej urbanistyki.

I tak, stopniowe wypełnianie Dolnego Tarasu uruchomiło procesy reurbanizacji, która w Gdyni nie miała takiej dynamiki jak w Gdańsku. Powstała dzielnica Gdynia-Zachód i inne elementy modelu miasta sieciowego (koncepcji w tym czasie popularnej), sieć wielkich marketów oraz hala sportowa.

Znakiem zwrotu jakościowego, którego z kolei jesteśmy świadkami dzisiaj, jest hasło „powrotu do miasta”. Wyraża się ono w znaczących decyzjach przestrzennych, obejmujących inwestycje służące zmienionej polityce przestrzennej, której celem jest wtórne ożywienie obszarów śródmiejskich - jako zbioru miejsc integrujących mieszkańców, przeciwdziałających społecznemu wykluczeniu, kreujących kulturę obywatelską. Obszerny katalog takich działań obejmuje w Gdyni stopniowe wycofanie się z najbardziej prymitywnych form organizacji handlu wielkopowierzchniowego (likwidacja centrum Gemini) i kreowanie w tych miejscach reprezentacyjnych programów miejskich (np. „Waterfront”), znaczących stref koncentracji funkcji publicznych, oraz - inspirowane m.in. doświadczeniami Nowego Jorku - przekształcanie najważniejszych ulic śródmiejskich w kierunku ich udostępniania wielu rozmaitym typom działalności. Ich wielofunkcyjność z przeznaczeniem także na potrzeby mieszkaniowe - aczkolwiek trudna w praktyce - jest dziś niezbędnym warunkiem życia miasta, jako miejsca bytowania wielu rozmaitych, połączonych wspólnym losem ludzi.

Pierwszym krokiem w tym kierunku była sanacja ulicy Świętojańskiej, nadal głównej ulicy Gdyni. Zakrojona na dość skromną skalę stanowiła wstęp do kolejnych realizacji. Dziś przygotowywane są programy: dla ulic Starowiejskiej oraz Abrahama, który, miejmy nadzieję, uda się wkrótce zrealizować oraz budowy Parku Centralnego (zamierzone skojarzenie z nowojorskim Parkiem Centralnym) przy ul. Piłsudskiego.

Gdyńskie inicjatywy urbanistyczne są - w zestawieniu, np., z gdańskimi parkami biznesu - dość skromne, ale można postawić pytanie: co raczej świadczy o nowoczesnym myśleniu: skale zamierzeń, będące m.in. funkcją potencjału gospodarczego określonego miasta, czy kierunek myślenia lepiej wpisujący się w ducha epoki?

\section{Gdynianie}

Powiedzieć, że Gdynię zbudowali jej mieszkańcy to byłby banał. To samo przecież można powiedzieć o każdym miejscu i trudno zakwestionować takie stwierdzenie. W przypadku Gdyni, w stwierdzeniu tym kryje się jednak coś szczególnego, jakaś „wartość dodatkowa”.

Port, z jego wyposażeniem, realizując potrzeby swojej gospodarki, zbudowało państwo. Mogłoby jeszcze wybudować parę osiedli pracowniczych dla zatrudnionych w nim i najpilniejsze potrzeby byłyby zaspokojone. Tylko czy wówczas nazywano by Gdynię „miastem z marzeń"? A marzenia to ludzie z całego kraju, którzy wymarzyli sobie, że odrodzona Polska będzie miała własny, prawdziwy port, swoje „okno na świat”, a także ci, którzy osiadłszy tu, postanowili nadać temu miejscu postać prawdziwego, nowoczesnego i pięknego miasta. Nadali mu też jego tożsamość. 
Tożsamość to coś, co w innych miastach powstaje i kształtuje się przez długie lata, czasem wieki, a niekiedy nie ujawnia się wcale. Gdynia potrzebowała na to kilkunastu lat, a właściwie, jej tożsamość od początku rodziła się i kształtowała razem z miastem. Tworzyli ją Gdynianie.

Kim byli? To trudno określić, przyjechali z całej Polski, przywożąc różne gwary, obyczaje, wzorce kulturowe. Szukali tu dla siebie życiowej szansy i miejsca na ziemi, materialnej poprawy losu i nowych doświadczeń, a chyba i nowych przygód. Były to bowiem niespokojne duchy, ludzie predestynowani do poszukiwania i tworzenia czegoś nowego. Tylko tacy mogli stworzyć fenomen Gdyni. Propagowana szeroko idea „Okna na świat” celnie trafiła do ich świadomości. Skutecznie krzewiła ją „Liga Morska i Rzeczna” i wiele innych organizacji społecznych, młodzieżowych i kulturalnych, a także literatura, prasa, radio ... W gruncie rzeczy nie zdajemy chyba sobie dziś sprawy jak ogromną pracę trzeba było wykonać, aby przeorientować $\mathrm{w}$ tej sferze zaściankowo-folwarczną świadomość narodu, pouczanego wiekami przez tradycję i kulturę, że „może nie wiedzieć Polak co to morze, gdy pilnie orze”. A jednak! Młodzi ludzie czytali Conrada i przyjeżdżali nad ten skrawek wybrzeża, do powstającego portu, aby realnie zetknąć się ze światem oceanów i mórz opisywanym przez tego Polaka, który zetknął się z nim, gdy musiał wyjechać z kraju. Oni już nie musieli. Dostęp do morza uzyskali razem z Niepodległością. Port budowało Państwo, ale Miasto budowali sami, zapewne na obraz swoich wyobrażeń i aspiracji.

Budowanie miasta od podstaw oznacza, rzecz prosta, wiele trudności, ale też niezwykłe możliwości swobodnego kształtowania jego struktury i formy, a także ekonomicznych podstaw funkcjonowania i charakteru. Bogata i urozmaicona mozaika społeczna budowniczych Gdyni uwalniała ich od ograniczeń płynących z tradycji, prowincjonalizmu, ksenofobii ... Byli oni natomiast, w sposób naturalny, podatni na nowoczesność, cokolwiek by to znaczyło. Pod tym względem byli podobni do pionierskich pokoleń Amerykanów. Jeśli uprawnione jest nazywanie Gdyni miastem modernistycznym, to nie tylko ze względu na unikatową architekturę. Jego społeczeństwo nie mniej na tę nazwę zasługiwało. Naturalna dynamika pionierów objawiła się ich wszechstronną przedsiębiorczością. Nowi Gdynianie szybko opanowywali nowe dla nich zawody i stanowiska, związane z funkcjonowaniem portu czy - szerzej - gospodarki morskiej. Sami podejmowali też wszechstronne inicjatywy, w wyniku których powstawały w szybkim tempie małe i średnie zakłady przemysłowe i handlowe, związane z dokonywanymi w porcie przeładunkami-bazującena importowanych towarach, przedsiębiorstwa połowu i przetwórstwa ryb, a przede wszystkim zróżnicowana i rozrastająca się sieć sklepów wszelkich branż. Handel stał się znakiem firmowym Gdyni.

Ta dynamika społeczna, skojarzona zaktywnym portem, który ze względu na swoje położenie był integralną częścią śródmieścia i krajobrazu Gdyni, przesądziły o wytworzeniu się tu czegoś szczególnego - aury miasta portowego. Co ciekawe, w powojennym Gdańsku, z jego tradycjami portowymi, tej aury tak się nie odczuwa. W Gdańsku dominują funkcje administracyjne, nauka, kultura i przemysł (stoczniowy), w Gdyni usadowiły się instytucje i placówki związane właśnie z morzem. Mieszkańcy Trójmiasta, bez względu na adres zamieszkania, zapytani o miasto portowe także skłonni będą wskazać raczej na Gdynię, Gdańskowi przyznając inne walory. 
Wojna poważnie przerzedziła przedwojenną społeczność gdyńską. Uzupełnili ją nowi przybysze, którzy często morza nigdy nie widzieli. Ale widocznie tożsamość Gdyni była na tyle silna, że wtopili się w nowe otoczenie i bardzo szybko przyjęli jego cechy, stali się Gdynianami, nie tylko w sensie administracyjnym.

Gdy nadeszły złe czasy dla wszelkiej inicjatywy prywatnej, kiedy podupadłe ekonomicznie państwo proklamowało tzw. „bitwę o handel”, Gdynia wykorzystując swoje specyficzne możliwości stwarzane przez port i bazującą w nim, rosnącą szybko flotę handlowa, przeciwstawiła się temu na swój sposób. Tak jak przed wojną stała się w Polsce oazą modernizmu, tak po niej objawiła się niepostrzeżenie jako oaza, jeśli nie kapitalizmu, to przynajmniej skromnej i nieostentacyjnej gospodarki wolnorynkowej. Na ulicy Świętojańskiej w Hali Targowej można było kupić prawie wszystko, co byli w stanie przywieźć do kraju obrotni marynarze. Skąd brali wymienialne środki finansowe i jak radzili sobie ze służbami celnymi, to ich zawodowa tajemnica.

Ostatnia transformacja przyniosła kolejne nadzieje. Miastem rządzili wizjonerzy: prezydent Franciszka Cegielska i jej zastępca Maciej Brzeski. Oni widzieli swoją „Gdynię Ogromną". Myśleli o realizacji przedwojennej wizji wielkiego portu okalającego Kępę Oksywska, o powstaniu na Oksywiu wielkiej Europejskiej bazy marynarki wojennej NATO, o budowie głębokowodnego nowego portu gdyńskiego na przedpolu obecnego, o nowych inwestycjach komunikacyjnych. Mieszkańcy Gdyni, weterani walk o wolny handel mieli nadzieję, że oczekiwana koniunktura przyniesie im nowe szanse.

Rzeczywistość okazała się nieco bardziej skomplikowana. Większy, wielofunkcyjny Gdańsk na wielu polach wygrywa dziś z Gdynią, a jego głębokowodny z rozległym zapleczem port - z pozbawionym tych walorów portem gdyńskim. Sławny ongiś, prywatny handel Gdyni źle znosi konkurencję ze współczesnymi wielkimi sieciami i galeriami handlowymi.

Gdynia w dalszym ciągu legitymuje się jednak doskonałymi rezultatami w gospodarowaniu miastem, choć czasy wielkich wizjonerów Kwiatkowskiego i Wendy, czy Cegielskiej i Brzeskiego, a chyba i bezimiennych bohaterów „inicjatywy prywatnej” ze Świętojańskiej i Hali Targowej, oddalają się, Gdynianie oczekują na nową koniunkturę i wierza, że nadejdzie. Mają rację.

\section{Literatura}

XV lat polskiej pracy na morzu, 1935, pod red. dr. Aleksego Majewskiego, nakładem Instytutu Wydawniczego Państwowej Szkoły Morskiej, Gdynia. 


\section{Gdynia - a city of the sea, dreams (and paradoxes)}

\section{ABSTRACT}

Creation of the port and the city of Gdynia was a political and economical necessity for Poland, just reborn after the 1st World War. The final success was a result of determination of the state and its citizens' resolution. Establishment of Gdynia marks the beginning of maritime tradition of Poland and its modern society. This is also a remarkable example of modern architecture.

Key words: city and port, society, modernism

Prof. arch. dr hab. Mieczysław Kochanowski, prof. zwyczajny Wyższej Szkoły Ekologii i Zarządzania, ul. Olszewska 12, Warszawa, em. prof. Politechniki Gdańskiej, były dziekan Wydziału Arch. PG, były prezes Zarzq̨du Głównego TUP, były członek GKUiR, były członek Państwowej Rady Gospodarki Przestrzennej, były dyrektor Zespołu Planowania Regionalnego w Komisji Planowania przy Radzie Ministrów.

Mieczysław Kochanowski, Professor Arch, PhD, Ordinary Professor of the University of Ecology and Management, Professor emeritus of the Gdansk University of Technology, former dean of the Faculty of Architecture of the Gdansk University of Technology, former President of the Society of Polish Town Planners, former member of GKUiR, former member of the State Council for Spatial Management, former director of the Regional Planning Team in the Planning Committee of the Council of Ministers. 